\title{
IDENTIFICATION AND MITIGATION OF SINKHOLE HAZARDS IN AN EVAPORITE KARST AREA (PERDIGUERA, SPAIN)
}

\author{
F.J. Torrijo ${ }^{1,3, *}$, R. Fuentes ${ }^{1}$, A. Boix ${ }^{2}$, P. Bracchi ${ }^{2, *}$ \\ ${ }^{1}$ Departamento de Ingeniería del Terreno, Universitat Politècnica de València, Valencia, Spain - fratorec@ttr.upv.es, r.fuentes@upv.es. \\ ${ }^{2}$ Facultad de Arquitectura y Urbanismo, Universidad UTE de Quito - (alberto.boix, paola.bracchi.83)@ute.edu.ec \\ ${ }^{3}$ Research Centre PEGASO, Universitat Politècnica de València, Valencia, Spain
}

Commission II - WG II/8

KEY WORDS: Karst, Sinkhole, Gypsum, Risk, Subsidence, Ebro Basin

\begin{abstract}
:
Sinkhole risks are becoming particularly severe in urban areas that lack careful planning and where karst depressions are frequently filled and developed. Sinkholes frequently have a higher probability of occurrence and a bigger genetic diversity in evaporite rocks than in carbonate rocks. This is because evaporites rocks (halite, gypsum, etc) have a higher solubility. Subsidence damage resulting from this dissolution generates considerable losses at the world. To contract with these risks, is needed the identification, investigation, prediction, and mitigation of sinkholes. Corrective measures might be applied to reduce the subsidence processes. A more practical solution for safe development is to reduce the vulnerability of the structures by using subsidence-proof designs. Therefore, this case study is located in the town of Perdiguera (Zaragoza, Spain), within the Ebro Basin. This town is affected by subsidence problems, which are associated with the dissolution of gypsiferous silts that generate sinking. These sinkholes are affecting the buildings threatening its structural integrity.
\end{abstract}

\section{INTRODUCTION}

\subsection{Sinkholes: a natural risk}

The term Sinkhole is a Slavic word used by geologists to designate closed depressions that present karst ground, those in which dissolution processes play a decisive role in the configuration of geomorphology. Sinkholes can be related to the dissolution of carbonated rocks (limestones and dolomites) or evaporitic rocks o soils (gypsums and salts), being the above mentioned much more soluble.

According to their genesis the sinkholes can be of two types (Gutiérrez et al., 2005-2006):

(1) Solution sinkholes, when they are due to differential karstification on the surface of soluble rock or soils. Solution sinkholes are commonly shallow depressions that may reach up to several meters across (Figura 1A). In Figure $1 \mathrm{~B}$ is showed a schema of solution sinkhole.

(2) Collapse sinkholes, in which subsurface karstification of soluble sediments causes gravitational deformation of the suprayacent sediments and the gradual or abrupt subsidence of the topographical surface.

Sinkholes, in addition to having a great interest from a geological point of view, in certain areas have a very relevant economic and social impact because of the risks and impacts that can arise from them.

According to Gutiérrez et al. (2008) and Galve et al. (2009), Spain is quite possibly the European country where the subsidence hazard related to evaporite karstification has the greatest economic impact, primarily because this type of formation underlies more than $7 \%$ of the territory. According to Galve et al. (2009) too, the Ebro Valley in the outskirts of Zaragoza city, carved in halite- and glauberite-bearing evaporites and gypsum silts, is the area in Spain where sinkholes cause the most economic damage. Dissolution-induced evaporite subsidence phenomena in this sector of the Ebro Tertiary Basin have been described in a number of papers.

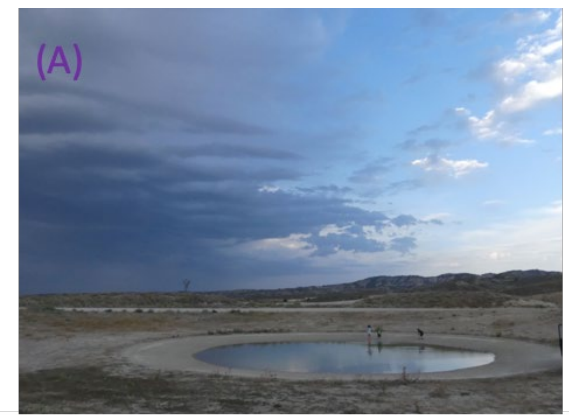

solution sinkhole

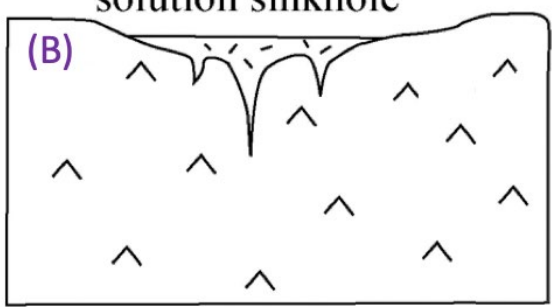

Figure 1. View of solution sinkhole on the surface of gypsum rock: (A) Panoramic view; (B) Interpretive scheme of solution sinkhole in (A).

* Corresponding author 
Thus, various authors have studied the impact of karstic subsidence on the evolution of fluvial systems (i.e. Gutiérrez and Arauzo, 1997; Benito et al., 1998; Guerrero et al., 2008a, 2008b; Galve et al., 2009, 2015; Guerrero, Gutiérrez, 2017).

\subsection{The town of Pediguera}

The town of Pediguera is located in the Ebro Basin, about $25 \mathrm{~km}$ northeast of Zaragoza, the capital of Aragon. Specifically, the area known as Los Monegros district (Figure 2). Its population is about 600 inhabitants and has an area of $110 \mathrm{~km}^{2}$.

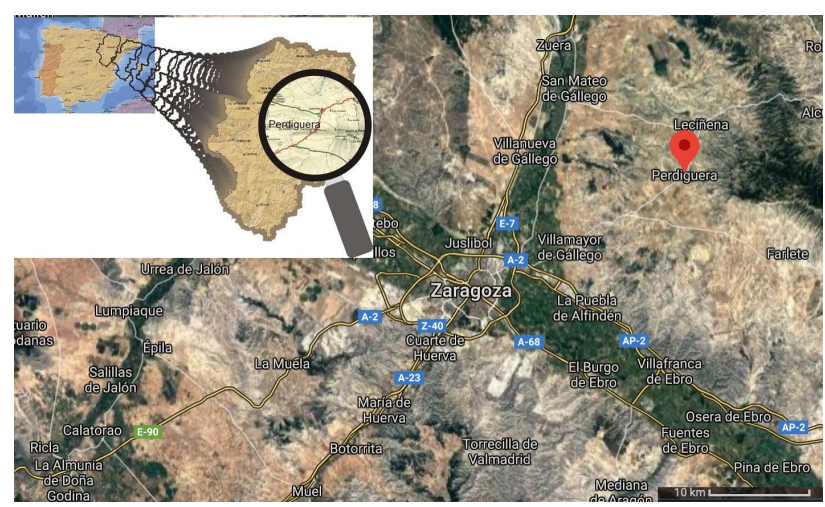

Figure 2. Location of Perdiguera.

This district (Los Monegros) is characterized by a landscape of desert character (Figure 3). This is a consequence of aridity caused by low precipitations, wind, erosion and endorreism.

Wide surfaces are occupied by areas of natural vegetation that interspersed with the crop fields, highlighting the steppes, the flat-top reliefs ("muelas"), gullies and salt-lakes ("saladas").

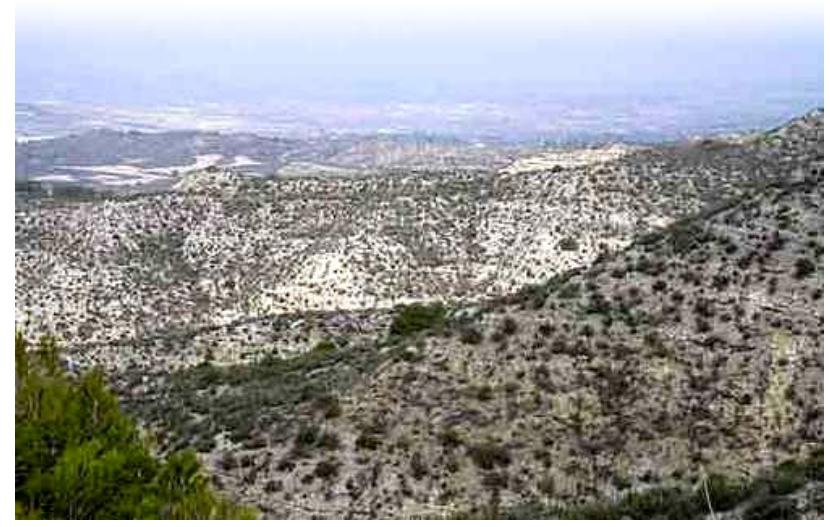

Figure 3. View of Los Monegros landscape.

Earthen architecture is traditional in Los Monegros. Also, it seems to show clearly that the adobe has been commonly used throughout the region constituting one of the possible materials (next to masonry and mud walls) with which to build the buildings of popular architecture (Figure 4).

In this context, when Perdiguera is visited, we can observe a great number of buiding ruins in the town and surroundings (Figure 5). And besides, solution sinkholes are affecting the buildings threatening its structural integrity. This is of great social significance because it prevents, and has prevented, a suitable development of the economy. It is also a source of problems, both for the people living in this town and for the municipal authorities.

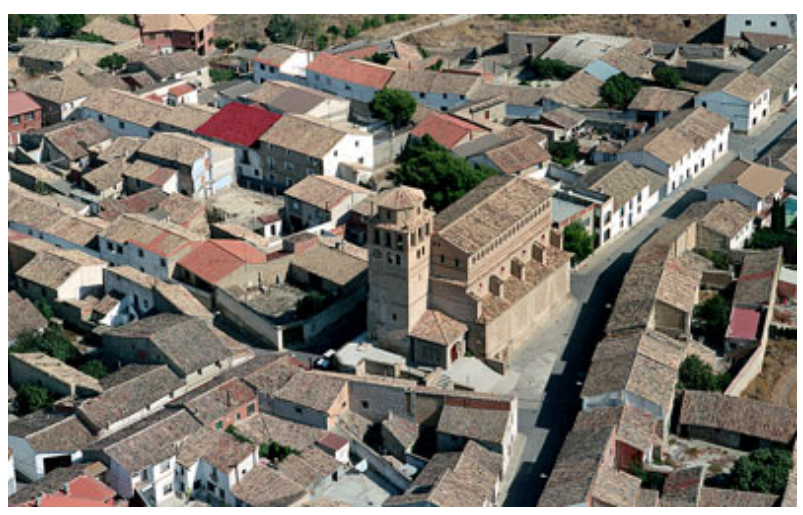

Figure 4. Aerial view of Perdiguera.

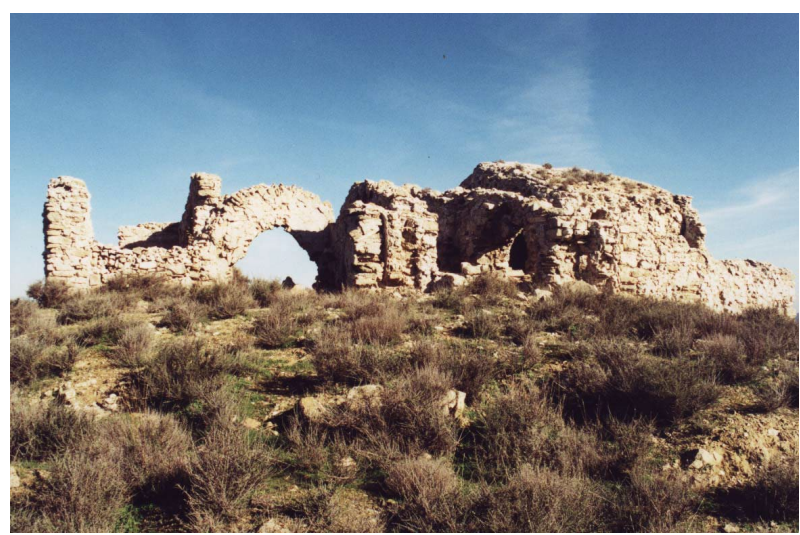

Figure 5. View of Santa Cruz Hermitage Ruins (Perdiguera).

\section{GEOLOGICAL-GEOTECHNICAL CHARACTERIZATION OF AREA}

From the geological point of view, Perdiguera is situated in the central sector of the Ebro Tertiary Basin, formed by the sedimentary contributions from the three mountain ranges that frame it (Pyrenees, Cordillera Ibérica and Coastal-Catalan Chains). It is filled by various materials in the Miocene, sedimented in marine and continental environments (Figure 6).

The latter deposits include from facies of alluvial fans in the margins of the basin (sandstones and claystones) to beach-lake facies in the center of the basin (with carbonated, gypsiferous and halitic deposits).

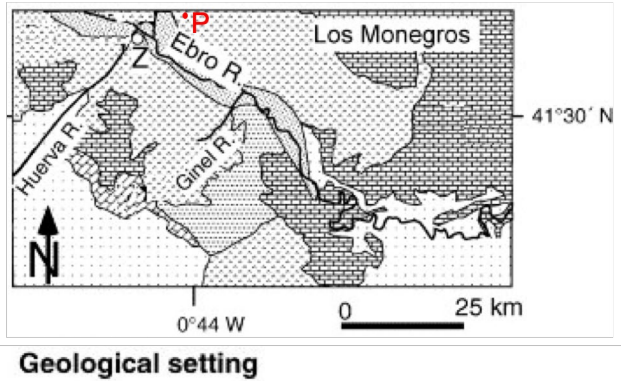

Ebro River

Quaternary deposits

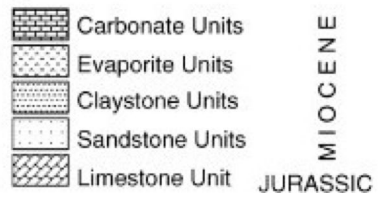

Figure 6. Geological location of Perdiguera (P) and Zaragoza (Z). Adapted of Valero et al. (2004). 
The Zaragoza Gypsum Formation (Quirantes, 1978) is the most important gypsiferous formation in this sector of Depression. In this sector, it presents massive, concretional and noduly gypsums. There are small intercalations of shales, marls and marly limestones. Its colors are white and white-grayish. Small levels of anhydrite, epsomite and halite are also common in them (Mandado, 1987). According to Klimowitz (1990), this formation locally reaches $800 \mathrm{~m}$ in thickness. In the subsurface the formation is primarily composed of various evaporitic minerals: i.e. halite, gypsum/anhydrite and glauberite (Salvany et al., 2007; Guerrero et al., 2008a, 2008b).

Since the beginning of the Quaternary, the installation and structuring of the fluvial network has occurred. This produced the erosion of tertiary materials and a very important alluvial sedimentation. On the one hand directly linked to the Ebro river and its tributaries (alluvial terraces); and on the other hand, controlled by the surrounding tertiary reliefs and connecting these with the river courses (glacis).

The logs of boreholes realized next to Perdiguera have been gathered. Three geotechnical units have been differentiated:

(1) Glacis deposits. This unit consists of brown gypsiferous silts and clays. Its thickness in the area reaches $15 \mathrm{~m}$ (Figure 7A).

(2) Clays with gypsum. It corresponds to a dark gray karstic residue developed at the top of the bedrock. Its thickness varies from 3 to more than $10 \mathrm{~m}$ (Figure 7B).

(3) Gypsum bedrock. Constituted for gypsum beds with interbedded marls. It is fresh bedrock and it has a asymmetrical geometry (Figure 7C).

On these units, anthropic waste and natural sinkhole fill deposits have been located in some points. Its thickness is variable.
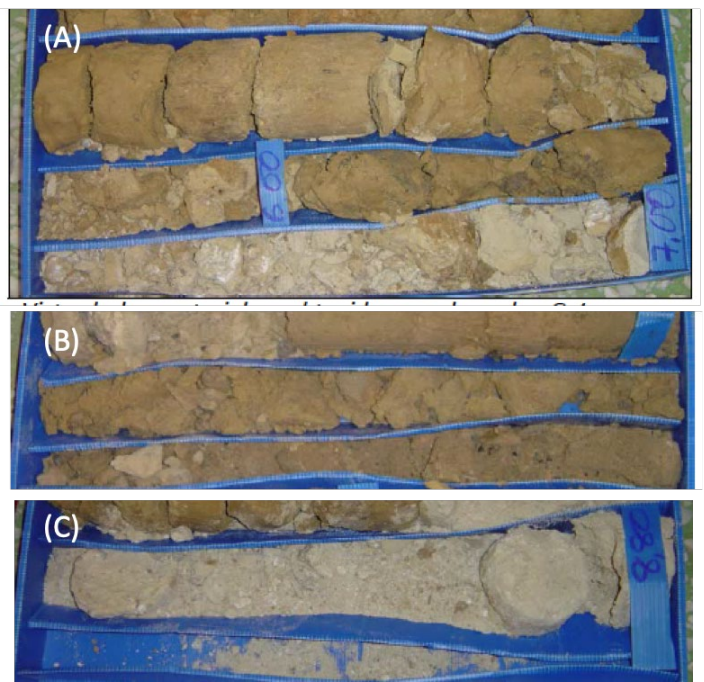

Figure 7. View of the units obtained in boreholes drilled: (A) Gypsiferous silts (glacis); (B) Clay with gypsum (altered bedrock); (C) Gypsum bedrock (Zaragoza Gypsum Formation).

\section{THE IMPACT OF HUMAN ACTIVITY}

Perdiguera is affected by subsidence problems, which are associated with the dissolution of gypsiferous silts (glacis deposits) that generate sinking.
The equilibrium solubilities of halite $(\mathrm{NaCl})$ and gypsum $\left(\mathrm{CaSO}_{4} 2 \mathrm{H}_{2} \mathrm{O}\right)$ explains why in evaporite karst cavities form and develop very quickly. Besides, these minerals have a appreciably lower mechanical strength and a more ductile rheology than the majority of soluble rocks. Additionally, these rock masses may deteriorate substantially at a human time-scale by quick dissolution guided by discontinuities. According to Gutiérrez et al. (2014), these circumstances explain why sinkholes in evaporite karst areas may be formed by a wider diversity of subsidence phenomenon.

Often, changes in the karst environment (naturals or anthropogenics) could accelerate the generation of sinkholes too, favoring or activating their incidence or revival.

In this sense, the foundations of most of the houses of Perdiguera, are based on glacis deposits (gypsiferous silts). These silts, in water-free conditions, have medium-strength characteristics (Torrijo and Cortés, 2008). However, at the moment of interaction with it, two processes are generated:

(1) A redistribution of its structure (which at first is very open and supported by sulphated point cements, gypsum).

(2) And simultaneously its dissolution ocurrs.

These two processes generate a significant decrease in the resistance of these deposits and generate important collapse processes by the appearance of hollows (dissolved areas).
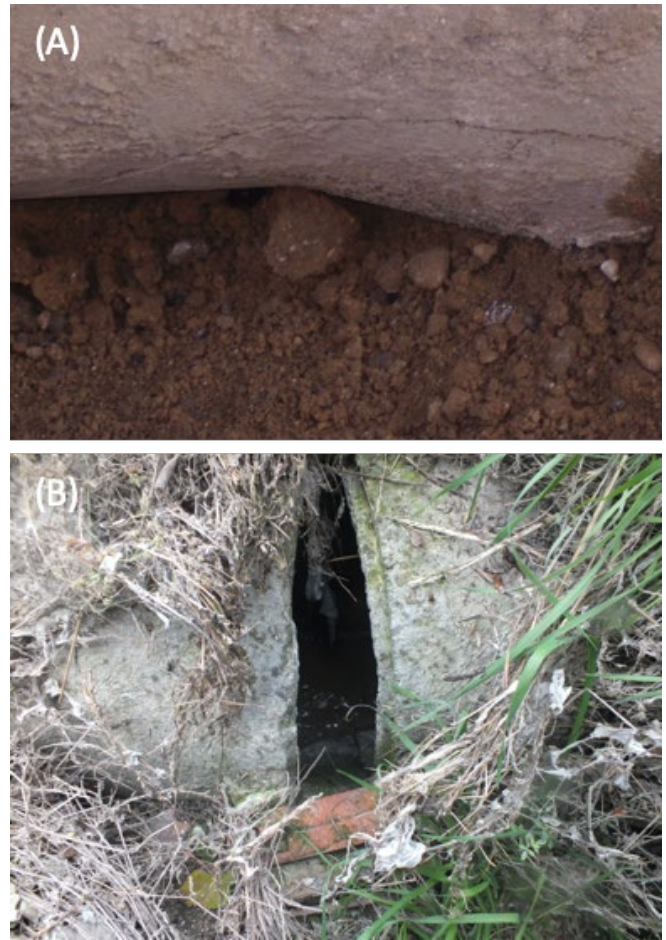

Figure 8. View of breaks in the water and sewer network of Perdiguera: (A) Crack in Del Medio Street Pipe; (B) Break in Main Collector.

There is also another detonating cause of this subsidence process due to human action: The existence of leaks and breaks in the water and sewer network (Figure 8) causes the collapse of the gypsiferous silts, whose visible effect is the cracks and subsidence detected in the houses and on the streets. 
These collapse processes produce much pathologies in Perdiguera buildings, as shown in Figures 9 and 10.
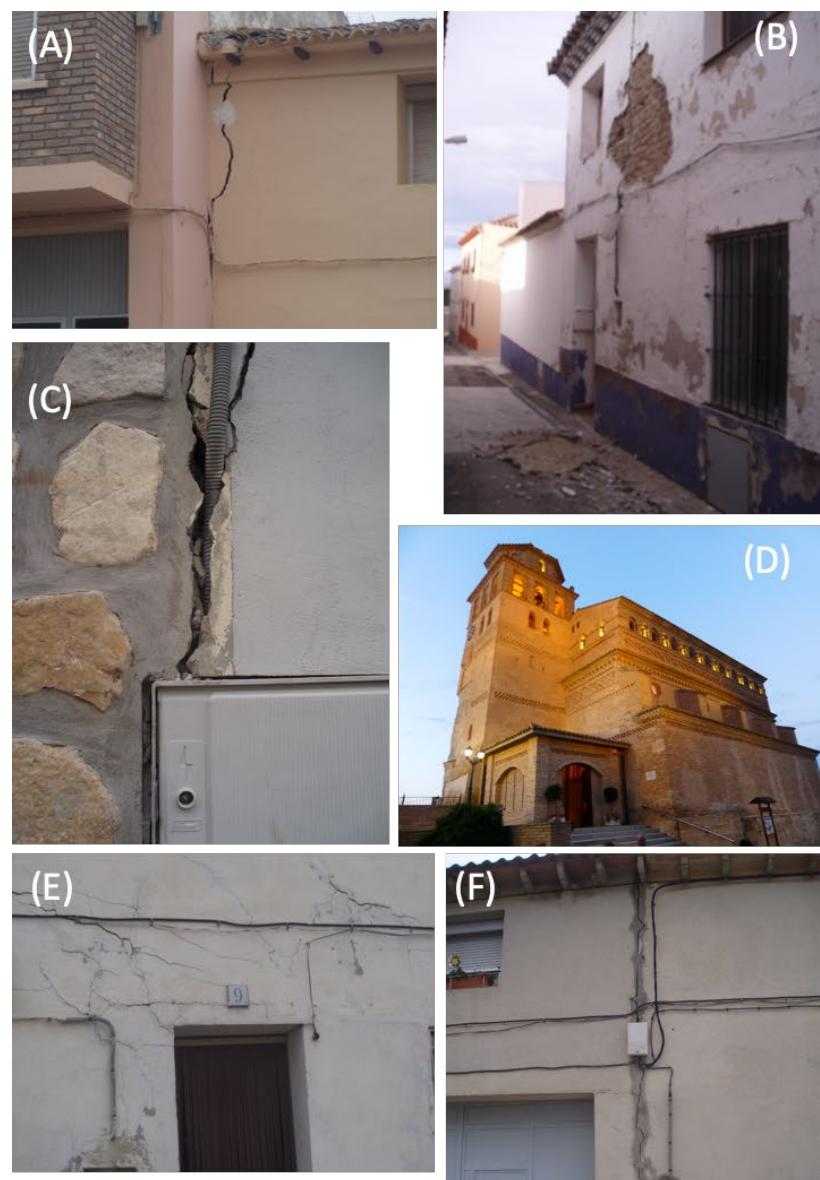

(G)
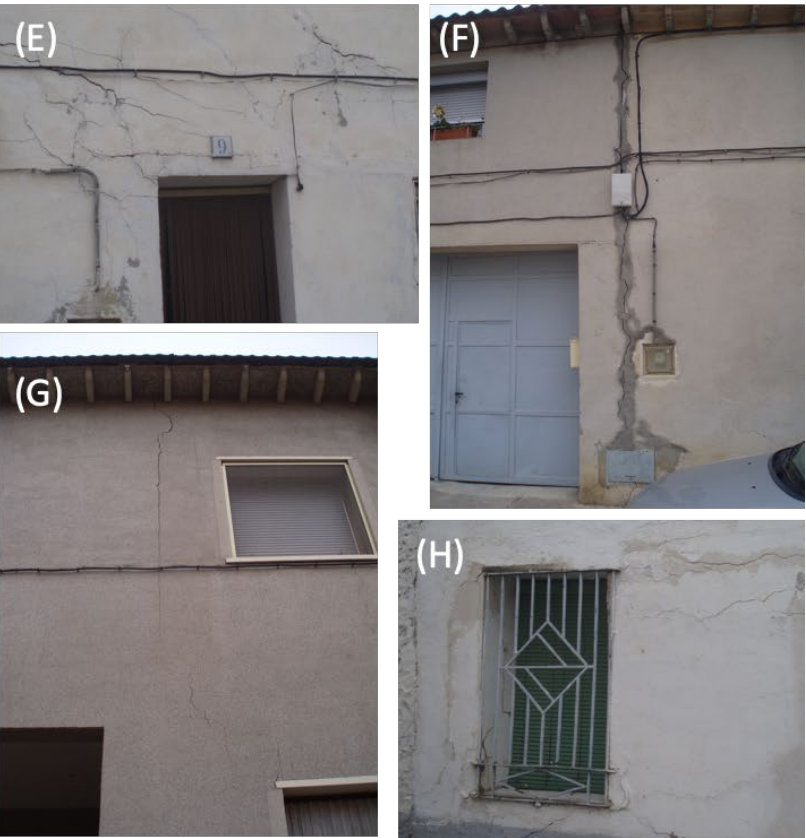

Figure 9. View of pathologies outside several Perdiguera buildings: (A) Plaza Altero, 7; (B) Calle del Medio, 6;

(C) Calle Palomar, 2-4; (D) $\mathrm{N}^{\mathrm{a}} \mathrm{S}^{\mathrm{a}}$ de la Asunción Church; (E) Calle Altero, 9; (F) Calle Tiro de la Bola, 20; (G) Calle Las Plazas, 1; (H) Calle Altero, 5.

Thus, finally, to explain in detail the process that occurs on the ground, it must be remembered that the silts present an open structure, in the form of "house of cards". This process is typical in saline sedimentary environments, where silt and clay particles form aggregates (small flocculates) and settle together in a random pattern (Figure 10A). Then, when the reorientation occurs due to the inflow of water (similar to freshwater sedimentary environment), these particles tend to accumulate in a dispersed structure with a parallel orientation (Figure 10B).
This house of cards structure, together with its gypsum component (highly soluble), makes them respond to an entrance of water to the ground diminishing its volume for reorganization of its structure (phenomenon of subsidence-collapse).

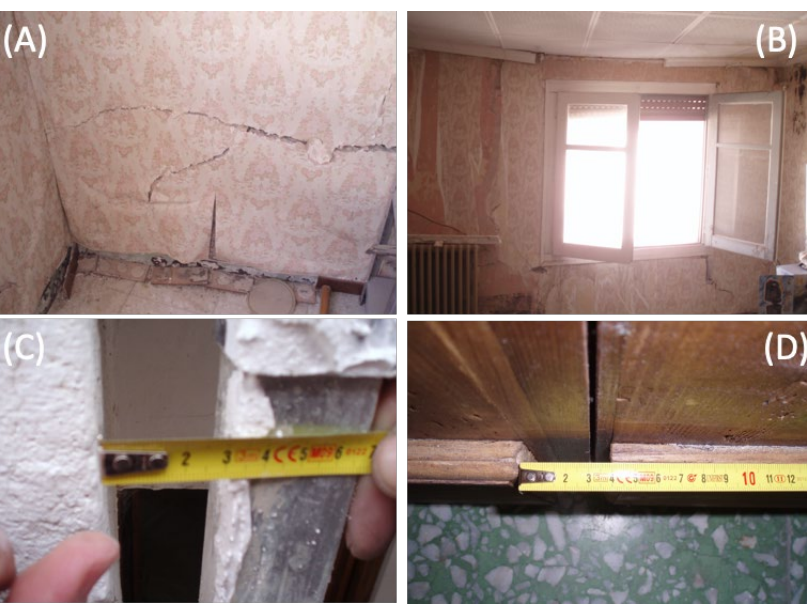

Figure 8. View of pathologies inside a Perdiguera building (6 Del Medio Street): (A) Wall cracks in the living room; (B) Cracks and deformation in a bedroom window; (C) Opening and deformation of a pile $(3 \mathrm{~cm})$; (D) Opening and deformation of the front door $(4 \mathrm{~cm})$.

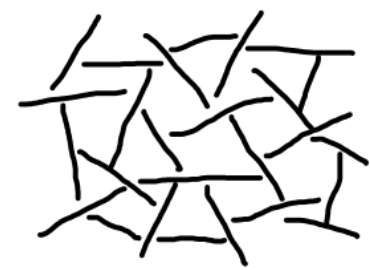

(A)

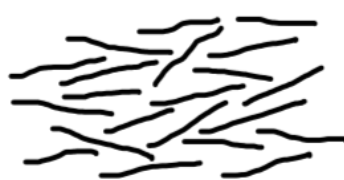

(B)
Figure 10. Scheme of collapse processes in silts: (A) Pre-collapse structure ("house of cards structure"); (B) Post-collapse structure.

\section{SINKHOLE RISK, IDENTIFICACION AND MITIGATION}

\subsection{Sinkhole risk identification}

According to Gutiérrez et al. (2014), the most important step in sinkhole hazard analysis is the construction of a comprehensive cartographic sinkhole inventory.

Depending on the information available, according to Galve et al. (2009b) and Gutiérrez et al. (2014), two types of models can be produced to predict the occurrence of future sinkholes: susceptibility models and hazard models.

\subsection{Sinkhole risk mitigation}

Several strategies (preventive measures) could take to reduce or eliminate the risks (economics and socials) related to sinkhole activity. According to Paukstys et al. (1999) and Buttrick et al. (2001), these measures could apply limiting development (or prohibiting) in the most hazardous areas through land use planning and regulations based on sinkhole susceptibility and hazard maps. In this sense, Gutiérrez et al. (2014) say: In order to minimize the impacts and hazards on these vulnerable and complex areas, man is head for learning how to "live with karst". 
In the specific case of Perdiguera, in its land use planning and regulations, we can propose the next corrective measures:

(1) Controlling the water table.

(2) Controlling irrigation.

(3) Coating of canals with impermeable material.

(4) Using flexible pipes with telescopic joints.

(5) Build efficient drainage systems.

(6) Using grouting to fill cavities in the ground.

(7) Increasing the strength and bearing capacity of the soils by compaction grouting.

And In the specific case of the houses with pathologies, the following corrective measurements are proposed:

(1) Review of the existing water and sewer network and replacement, if necessary, by pipes built with flexible materials. This will prevent the abrupt breakage of the pipes by a specific failure in the ground.

(2) Underpinning of existing foundations. In this sense, the solutions could go through the execution of micropiles, consolidating injections, etc.

(3) Future topographical control of the vertical and horizontal movements of the building, to confirm that the treatment is being effective.

\section{CONCLUSIONS}

The conservation of architectural, cultural and social heritage is a fundamental task for the preservation of our history and culture. However, nowadays, as in the past, the risk of natural disasters, such as subsidences, threatens this heritage constantly. Within Spain architectural heritage, earthen architecture is one of the main building traditions and is often threatened by natural hazards.

In this sense, Perdiguera is affected by subsidence problems, which are associated with the dissolution of gypsiferous silts (glacis deposits) that generate sinking. These sinkholes are producing much pathologies in Perdiguera buildings.

Thus, through the study of the case of Perdiguera, this research wants to provide a detailed analysis of a natural hazard called sinkholes, and also identifying conservation strategies. So, some corrective measures have been proposed in land use planning and regulations of Perdiguera.

Finally, the definition of these strategies has a specific and general nature in order to be applied not only to the case study, but also to similar cases.

\section{ACKNOWLEDGEMENTS}

The authors of this article would like to thank the Ibergeotecnia, S.R.L. for providing the initial data. Also, thanks to María Estefanía Bona, MSc and Jesús Juan Usón for their contribution on this article.

This paper is related with the research project "RISK-Terra. Earthen architecture in the Iberian Peninsula: study of natural, social and anthropic risks and strategies to improve resilience" (RTI2018-095302-B-I00), funded by the Spanish Ministry of Science, Innovation and Universities.

\section{REFERENCES}

Benito, G., Pérez-González, A., Gutiérrez, F., Machado, M.J., 1998: River response toQuaternary subsidence due to evaporite solution (Gállego River, Ebro Basin, Spain). Geomorphology 2, p.243-263.

Buttrick, D.B., van Schalkwyk, A., Kleywegt, R.J., Watermeyer, R.B., 2001: Proposed method for dolomite land hazard and risk assessment in South Africa. Journal of the South African Institution of Civil Engineers, 43, p.27-36.

Galve, J.P., Castañeda, C., Gutiérrez, F., Herera, G., 2015: Assessing sinkhole activity in the Ebro Valley mantled evaporite karst using advanced DInSAR. Geomorphology, 229, p.30-44.

Galve, J.P., Gutiérrez, F., Lucha, P., Bonachea, J., Remondo, J., Cendrero, A., Gutiérrez, M. Gimeno, M.J., Pardo, G., Sánchez, J.A., 2009: Sinkholes in the salt-bearing evaporite karst of the Ebro River valley upstream of Zaragoza city (NE Spain). Geomorphological mapping and analysis as a basis for risk management. Geomorphology, 108, p.145-158.

Guerrero, J., Gutiérrez, F., 20017: Gypsum scarps and asymmetric fluvial valleys in evaporitic terrains. The role of river migration. Landslides, karstification and lithology (Ebro River, NE Spain). Geomorphology, 297, p.137-152.

Guerrero, J., Gutiérrez, F., Lucha, P., 2008a: The impact of halite dissolution subsidence on fluvial terrace development. The Case Study of the Huerva River in the Ebro Basin (NE Spain). Geomorphology, 100, p.164-179.

Guerrero, J., Gutiérrez, F., Bonachea, J., Lucha, P., 2008b: A sinkhole susceptibility zonation based on paleokarst analysis along a stretch of the Madrid-Barcelona high-speed railway built over gypsum- and salt-bearing evaporites (NE Spain). Engineering Geology, 102, p.62-73.

Gutiérrez, F., Arauzo, T., 1997: Subsidencia kárstica sinsedimentaria en un sistema aluvial efímero: El Barranco de Torrecilla (Depresión del Ebro, Zaragoza). Cuadernos de Geología Ibérica, 22, p.349-372.

Gutiérrez, F., Muñoz, A., Coloma, P., 2005-2006: Dolinas de subsidencia y de colapso en el Karts carbonatado-aluvial de Grávalos (La Rioja). Origen y evolución. Zubía, 23-24, p.59-78.

Gutiérrez, F., Calaforra, J.M., Cardona, F., Ortí, F., Durán, J.J., Gary, P., 2008: Geological and environmental implications of evaporitic karst in Spain. Environmental Geology, 53, p.951-965.

Gutiérrez, F., Parise, M., De Waele, J., Jourde, H., 2014: A review on natural and human-induced geohazards and impacts in karst. Earth-Sciences Reviews, 138, p.61-88.

Mandado, J., 1987: Litofacies yesíferas del Sector Aragonés de la Cuenca Terciaria del Ebro. Petrogénesis y geoquímica. Doctoral Thesis. Zaragoza: Universidad de Zaragoza.

Paukstys, B., Cooper, A.H., Arustiene, J., 1999: Planning for gypsumgeohazard in Lithuania and England. Engineering Geology, 52, p.93-103.

Quirantes, J., 1978: Estudio sedimentológico y estratigráfico del Terciario continental de los Monegros. Inst. Fernando El Católico, Excma. Dip. Zaragoza. Zaragoza. 
Salvany, J.M., García-Veigas, J., Ortí, F., 2007. Glauberitehalite association of the Zaragoza Gypsum Formation (LowerMiocene, Ebro Basin, NE Spain). Sedimentology, 54, p.443-467.

Torrescusa, S., Klimowitz, J., 1990: Contribución al conocimiento de las evaporitas Miocenas (Fm. Zaragoza) de la Cuenca del Ebro. In: Ortí, F., Salvany, J.M. (Eds.), Formaciones evaporíticas de la Cuenca del Ebro, cadenas periféricas y de la zona de Levante. Enresa, Barcelona, p.120-123.

Torrijo, F.J., Cortés, R. 2008: Estudios geológico-geotécnico realizado para determinar las causas de patologías existentes en la vivienda de la calle del Medio $\mathrm{n}^{\circ} 6$ de Perdiguera (Zaragoza). No Informe: 2008/1229. Ibergeotecnia, S.R.L., Zaragoza.

Valero-Garcés, B.L, González-Sampériz, P., Navas, A., Machín, J., Delgado-Huertas, A., Peña-Monné, J.L., Sancho-Marcén, C., Stevenson, T., Davis, B., 2004: Paleohydrological fluctuations and steppe vegetation during the last glacial maximum in the central Ebro valley (NE Spain) Quaternary International, 122, p.43-55. 